\title{
尺骨神経刺激による小指球からのM波
}

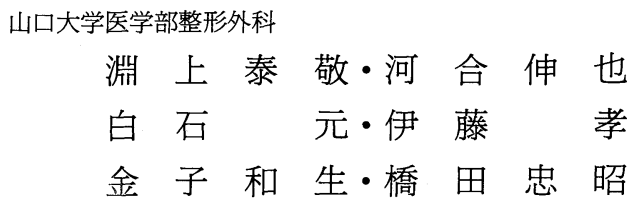

\section{M-wave recorded over the Hypothenar Eminence elicited by Ulnar Nerve Stimulation}

by

\author{
Yasunori Fuchigami, Shinya Kawai, Gen Slıi aishi, Takashi Ito, \\ Kazuo Kaneko and Tadaaki Hashida \\ Department of Ortho edic Surgery, University o $o_{\perp}$ amaguchi, \\ U e, Yamaguchi, Japar
}

\begin{abstract}
In general, configuration of $\mathrm{M}$-wave shows a simple dome-shape by belly-tendon montage. The M-wave recorded over the hypothenar eminence elicited by ulnar naerve stimulation often has double peaks in the negative phase. The origin of this double-peaked response has not been clarified. To investigate the origin of these double peaks, we recorded ulnar M-waves from abductor digiti minimi, 1st dorsal interossei, and adductor pollicis simultaneously in 11 hands of six normal volunteers, in two cases of Guyon's canal syndrome and in two cases of ulnar nerve injury at the wrist. In the seven hands of normal volunteers, we recorded double-peaked M-waves from abductor digiti minimi. The latency of the second peak corresponded to the peak latency of the 1st dorsal interossei and adductor pollicis. In the two cases of Guyon's canal syndrome and in the two cases of ulnar nerve injury at the wrist, $\mathrm{M}$-waves from abcuctor digiti minimi were a simple domeshape. In those cases $\mathrm{M}$-waves from the 1 st dorsal interossei and adductor pollicis were almost absent. We concluded that M-waves from the 1st dorsal interossei and adductor pollicis influenced the second peak of the $\mathrm{M}$-wave recorded over the hypothenar eminence.
\end{abstract}

Key words：M-wave (M 波), Hypothenar Eminence (小指球), Ulnar Nerve (尺骨神経)

一般にM波はドーム状の陰性相とそれに続く陽性相 よりなり，陰性相のピークはひとつであることが多い. 尺骨神経刺激により得られる小指球のM波の陰性相が double peak を呈すことについては，尺骨神経支配の intrinsic muscle の数が多いためか, 腱上の不関電極 が電気的に inactive ではないためとも考元られてい るが，いまだ定説はない．母指側からのM波を同時に
記録し，小指球からの double peak の由来検討した ので報告する。

\section{対 象}

$17 \sim 34$ 才（平均年齢 26 才）の健常人 6 名 11 手お よび，ギヨン管症候群 2 例，手関節部尺骨神経損傷 2 例を対象とした。 


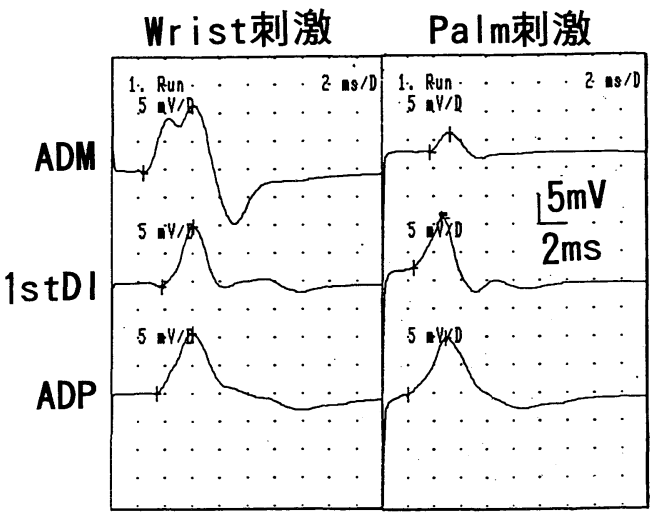

図 1 尺骨神経刺激によるM波，34 歳健常男性

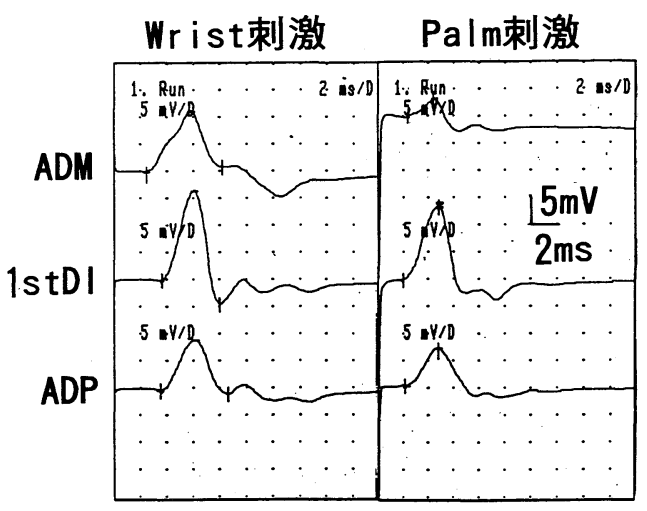

図 2 尺骨神経刺激によるM波，32 歳健常男性

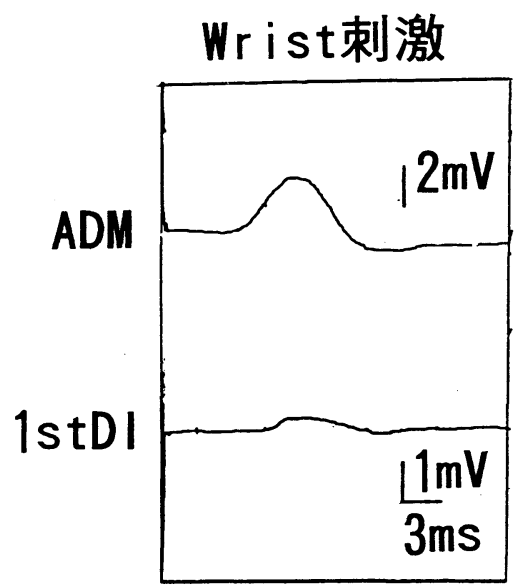

図 3 手関節部尺骨神経損傷, 33 歳男性, 神 経縫合術後 1 年
方法

健常人（17～34才） 6 人 11 手に対しては手関節部 および手掌にて尺骨神経を刺激し，小指外転筋，母指 内転筋，第 1 背側骨間筋より M波を表面電極にて同時 記録した。ギヨン管症候群，手関節部尺骨神経損傷例 においては手関節部にて尺骨神経を刺激し，小指外転 筋，第 1 背側骨間筋よりM波を記録した。

\section{結果}

健常人での手関節部刺激による小指球 (小指外転筋) からのM波が明らかな double peak を呈するものは 11 手中 8 手, single peak を呈すものは 3 手であった. 母指内転筋，第 1 背側骨間筋の M 波は全例 single peak を呈した。

手関節部刺激による各筋の初期潜時, 頂点潜時, 陰 性相持続時間を示すと, double peak を呈した小指外 転筋のふたつ目の peak は平均 $6.2 \pm 0.5 \mathrm{~ms}$ ，母指内転 筋，第 1 背側骨間筋の頂点潜時はそれぞれ $6.1 \pm 0.5$, $5.9 \pm 0.3 \mathrm{~ms}$ とほぼ一致した。また，陰性相持続時間 は小指外転筋, 平均 $5.4 \pm 0.4 \mathrm{~ms}$, 母指内転筋, $4.3 \pm$ $0.5 \mathrm{~ms}$ ，第 1 背側骨間筋， $3.9 \pm 0.5 \mathrm{~ms}$ と，小指外転筋 において長い傾向にあった。これは尺骨神経支配のい くつかの筋由来のM波の加算によるためと考えた。

手掌刺激による小指外転筋のM波は 11 手中 8 手が single peak を呈した. その頂点潜時は $5.2 \pm 0.6 \mathrm{~ms}$ で

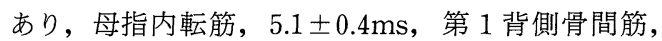
$5.0 \pm 0.4 \mathrm{~ms}$ と, ほぼ一致した。これらより double peakのふたつ目の陰性頂点は母指側の容積伝導と考 える。

34 才男性例では手関節部刺激による小指外転筋の M波は double peak であり，ふたつ目の院性頂点の 潜時は母指側の陰性頂点とほぼ一致していた。手掌刺 激による小指外転筋の M波は single peak を呈し，母 指側の陰性頂点とほぼ一致していた（図 1 ).

32 才男性例では手関節部刺激および手掌刺激によ る小指外転筋のM波はいずれも single peakを呈し， 母指側の陰性頂点とほほ一致していた（図 2 ).

ギヨン管症候群，手関節部尺骨神経損傷例はいずれ も手関節部刺激による小指外転筋の $\mathrm{M}$ 波は single peak を呈した。同時に記録した母指内転筋，第 1 背 側骨間筋のM波は消失，あるいは極めて低振幅であっ た。 
手関節部尺骨神経損傷例においては第 1 背側骨間筋 のM波がきわめて小さく，小指球の M波は single peakを呈した（図 3 )。

\section{考察}

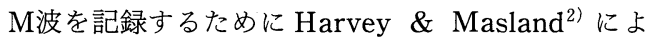
り考案された belly-tendon 法は運動神経伝導速度測 定のための方法として広く普及している．筋肉の電気 的な活動は motor point と呼ばれる motor end plate から生じるとされ，ここに関電極を置き，不関電極は 腱（あるいは骨性隆起）に置く。一般に腱上は電気的 に inactive とされており，このため，M波は陰性に ドーム状にふれ（陰性相），ついで陽性にふれ，基線 にもどる形を呈し, 通常, 陰性相のピークはひとつと なる，正中神経刺激による母指球の M波の陰性相は simple dome となるが，しかしながら，尺骨神経刺 激により得られる小指球の M波の陰性相は double peak を呈すことが多い. Double peak の由来はいま だ定説がなく，1）尺骨神経支配の intrinsic muscle の数が多い，2）個々の筋肉内の神経線維の arrangement が尺骨神経と正中神経では異なる，3) 腱上の不関電極が電気的に inactive ではない，とい う説がある. Kincaid ${ }^{4)}$ は不感電極を小指から母指 などに変更し，小指基節部が電気的に active である ことを示し，尺骨神経支配の muscle mass が多いた め, volume conductor の変化により生じる far field potential (遠隔電場電位) がふたつ目の頂点を形成 するとした。

尺骨神経刺激による小指球のふたつ目の頂点が母指 内転筋や第 1 背側骨間筋の陰性頂点とほほ一致し, 手 掌刺激において小指球のM波が single peak となり， 尺骨神経損傷等において，母指内転筋や第 1 背側骨間 筋の $\mathrm{M}$ 波がきわめて小さい場合，小指球の $\mathrm{M}$ 波が single peak となることにより，尺骨神経支配の intrinsic muscle の数が多く，その容積伝導 ${ }^{3)}$ により double peak 呈すと考える.

母指球を形成する筋のうち母指内転筋は面積, 筋力 ともに最も大きい1) とされており，第 1 背側骨間筋と ともに，第 3 ，第 4 虫様筋，掌側骨間筋よりも double peak の形成に大きく関与すると考える.

小指球のふたつ目の頂点と母指側の筋の陰性頂点が 完全に一致しないのは第 3 , 第 4 虫様筋，掌側骨間筋 等のM波の陰性頂点や陽性相の波形によるものと考元 る. 今後, 尺骨神経損傷等の経過を追い, 母指内転筋 や第 1 背側骨間筋のM波の出現と小指球のふたつ目の 頂点との相関を検討したい.

\section{結語}

尺骨神経刺激により得られる小指球のM波の陰性相 が double peak を呈すのは尺骨神経支配の intrinsic muscle の数が多いためと考えた。とりわけ母指側の 母指内転筋や第 1 背側骨間筋が大きいため，これらの 陰性頂点が小指球の $\mathrm{M}$ 波のふたつ目の頂点とほぼ一致 すると考える。

\section{参 考 文 献}

1) Fahrer $\mathrm{A}$ : The Thenar Eminence : An Introduction. The Hand Vol. 1, pp. 255-258. Edited by R. Tubiana, Philadelphia, W. B. Saunders, 1981.

2) Harvey AM, Masland RL : A Method for the Study of Neuromuscular Transmission in Human Subject. Bull Johns Hopkins Hosp, 68 : 81-93, 1941.

3）長谷川修ら：運動神経伝導速度の電位の波及と刺激の 波及, 臨床脑波, 36：191-194，1994。

4) Kincaid JC, Brashear A, Markand ON : The Influence of the Reference Electrode on CMAP Configuration. Muscle \& Nerve, $16: 392-396,1993$. 